Dr. sc. Miodrag Mićović, redovni profesor

Pravni fakultet Univerziteta u Kragujevcu

\title{
VRHUNSKI SPORT
}

UDK: 796. 034.06

Primljeno: 15.12. 2017.

Izvorni znanstveni rad

Koncept vrhunskog sporta, koji se zasniva na pružanju podrške radi postizanja vrhunskih rezultata, počeo je da se razvija u drugoj polovini prošlog veka. U nekim zemljama, on se temelji na novčanoj podršci koju država pruža vrhunskim sportistima, dok se u drugim, pored finansijske podrške, primenjuju i druge mere koje treba da olakšaju sportistima bavljenje sportom, kao i drugim aktivnostima. U vezi sa tim u članku su izložena pitanja koja se tiču: osnova na kojima se zasniva vrhunski sport; uslova koje treba ispuniti kako bi se stekao status vrhunskog sportiste; efekata koji nastaju dobijanjem statusa vrhunskog sportiste; osnova za gubitak prava koja proističu iz statusa vrhunskog sportiste.

Ključne reči: vrhunski sport, vrhunski sportist, status, takmičenje, mere

\section{VRHUNSKI SPORT U FUNKCIJI OSTVARENJA JAVNOG INTERESA}

Sport pruža brojne koristi, kako za pojedince tako i za celo ljudsko društvo (na međunarodnom, nacionalnom, regionalnom, lokalnom nivou). ${ }^{1}$ To je razlog što se u svim zakonima kojima se uređuje sport ističe da je sport društveno korisna delatnost, ${ }^{2}$ odnosno delatnost od posebnog značaja za društvo. ${ }^{3} \mathrm{U}$ vezi sa tim određuje se da je u javnom (opštem) interesu: podsticanje razvoja sporta, posebno kod dece i mladih; izgradnja i održavanje sportskih objekata; podsticanje delovanja nacionalnih sportskih saveza, olimpijskog i paraolimpijskog komiteta; obezbeđenje uslova za trening sportista, sportsko-rekreativne aktivnosti dece, mladih i građana; obezbeđenje uslova za sprovođenje međunarodnih takmičenja; dodeljivanje priznanja

1 Bavljenje sportom omogućava svakom ljudskom biću razvoj fizičkih i intelektualnih snaga, doprinosi unapređenju zdravlja, rehabilitaciji i integraciji osoba sa invaliditetom, pospešuje razumevanje etičkih vrednosti, uči toleranciji i odgovornosti. Za svako društvo sport je od značaja jer promoviše veće zajedništvo među ljudima (ali i narodima), usmerava energiju dalje od potencijalnog nasilja, doprinosi promovisanju humanističkih vrednosti, uzajamnom razumevanju i zbližavanju ljudi. O tome: Đurđević, N., Mićović, M., Vuković, Z., Ugovori o sportu, Kragujevac, 2014., str. 22. 271.

2 Šuput, D., „Zakonsko uređivanje sporta u evropskim državama“, Strani pravni život, br. 3/09, str.

3 Videti: čl. 2. st. 1. Zakona o sportu Republike Srbije (Sl. glasnik RS, br. 10/16; u daljem tekstu ZOSRS) ili čl. 1. st. 2. Zakona o sportu Republike Hrvatske (Narodne novine RH, br. 71/06, 150/08, 124/10, 124/11, 86/12, 94/13, 85/15, 19/16; u daljem tekstu ZOSRH). 
i nagrada za doprinos razvoju i afirmaciji sporta; organizacija naučnih sportskih skupova i izdavanje sportskih publikacija. ${ }^{4}$ Jedan od tih interesa, koji se definiše i konkretizuje pomoću odgovarajućih pravila, je briga o vrhunskim sportistima, kroz obezbeđivanje potrebnih uslova za pripremu, školovanje, stipendiranje itd. ${ }^{5}$

Vrhunski sportisti predstavljaju jednu od tri kategorije sportista. Za razliku od amatera i profesionalnih sportista, čije se svrstavanje vrši na bazi socijalnih i ekonomskih faktora (da li se sportom bave u vidu zanimanja, bez naknade ili uz naknadu), za status vrhunskih sportista od značaja je sportski faktor, ostvaren rezultat na odgovarajućem takmičenju, ${ }^{6}$ koji društvo, putem pravila koja donosi, proglašava kao vrhunski i na određeni način podržava. Ovo znači da se vrhunski sport ${ }^{7}$ zasniva na recipročnom angažmanu države i sportskog pokreta ${ }^{8}$ (volje da se pomogne i volje da se ostvari određeni rezultat), ${ }^{9}$ da je državni intervencionizam posebno izražen u ovoj oblasti sporta, da se na vrhunski sport primenjuje intervencionistički model uređenja ${ }^{10}$ odnosno tzv. birokratski koncept. ${ }^{11}$

Koncept vrhunskog sporta, koji se zasniva na pružanju podrške radi postizanja vrhunskih rezultata, počeo je da se razvija 80-tih godina prošlog veka. Tada počinje da se razvija ideja o potrebi kontrole elitnog sporta od strane države i njegovo podvođene pod plašt javnog interesa. ${ }^{12}$ Ideja je motivisana nastojanjem da elitni sport posluži kao sredstvo promocije države ${ }^{13}$ na međunarodnom i unutrašnjem planu (po

4 Videti: čl. 11. Zakona o sportu Republike Crne Gore (Sl. list CG, br. 36/11, 36/13; u daljem tekstu ZOSRCG), čl. 112. ZOSRS, čl. 75. ZOSRH.

5 U Zakonu o sportu Kraljevine Španije (čl. 6) određuje se da će država, zajedno sa regijama, raditi na stvaranju tehničkih uslova za razvoj vrhunskog sporta, da će obezbediti medicinsku i naučnu podršku vrhunskom sportu, da će sprovesti mere uz pomoć kojih će vrhunski sportisti biti uključeni u obrazovni sistem, kao i one koje će doprineti da se sportisti socijalno i profesionalno integrišu u društvenu zajednicu (videti: Šuput, D., nav. članak, str. 263).

6 Buy, F. i dr., Droit du sport, Paris, 2009., str. 299.

7 Oblast sporta koja obuhvata sportske aktivnosti koje za rezultat imaju izuzetne (vrhunske) rezultate i sportske kvalitete (čl. 3. st. 1. tač. 4. ZOSRS).

8 Simon, G., Puissance sportive et ordre juridique étatique, Paris, 1990., str. 363.

9 Vrhunski sport objedinjuje postojanje dobrog rezultata, volju da se rezultat postigne i finansijsku potporu. O tome: Đurđević, N., Mićović, M., Vuković, Z., nav. delo, str. 19.

10 Intervencionistički model znači da je u određenoj državi sport uređen normama koje su uglavnom sadržane u posebnom zakonu o sportu (Francuska, Crna Gora, Mađarska, Makedonija, Italija, Luksemburg, Rumunija, Hrvatska, Slovenija, Španija), a neintervencionistički model znači da su norme koje se tiču sporta pretežno raspoređene u sektorskim propisima koji uređuju obavljanje nekih drugih ljudskih delatnosti (Velika Britanija, Danska, Nemačka, Kipar, Češka Republika). Neke zemlje se opredeljuju da u svojim zakonima o sportu regulišu isključivo obaveze državnih organa u pogledu ostvarivanja javnog interesa (Austrija, Finska, Litvanija, Švajcarska). O tome: Šuput, D., nav. članak, str. 253, 255.

11 U zavisnosti od uloge pojedinih subjekata u odvijanju sportskih aktivnosti pojedini autori razlikuju misionarski, preduzetnički, društveno dogovorni i birokratski sistem (sport i prateće aktivnosti uređuje i njima upravlja javna vlast) uređenja sporta. O tome: Zintz, TH., L'approche des associations et des fédérations sportives, Bruxelles, 2010., str. 20.

12 Fleuriel, S., Sport de haut niveau ou sport d'élite, http://sebastien.fleuriel.free.fr/IMG/pdf/ TheseFleuriel.pdf, str. 11.

13 Kako je prepoznato da vrhunski sportisti na najbolji način promovišu zemlju koju predstavljaju, uočljivo je da se širi broj disciplina i sportista koji imaju status vrhunskog sporta (sportiste), s tim što sa sticanjem statusa preuzimaju i obavezu da promovišu vrednosti svoje zemlje. S tim u vezi, u Francuskoj je 
pravilu, većina stanovništva uspehe sportista na velikim takmičenjima doživljava kao izraz snage i mogućnosti zemlje). ${ }^{14}$ Pored zadovoljenja javnog interesa, dobro postavljen koncept vrhunskog sporta treba da pruži šansu sportistima da ostvare uspeh na društvenom i profesionalnom planu, ${ }^{15}$ mogućnost efikasnog pomirenja sportskog i izvan sportskog života, za vreme i nakon prestanka bavljenja sportom. ${ }^{16}$

Značaj koji za državu ima vrhunski sport jasno proističe iz Strategije razvoja sporta u Republici Srbiji za period 2014 - 2018. godine. ${ }^{17}$ U njoj se (odeljak o misiji sporta) u prvi plan stavlja potreba preduzimanja mera u cilju unapređenja kvaliteta života i obogaćivanje društvenih odnosa stanovnika, što podrazumeva, pored ostalog (stvaranje mogućnosti da se svi bave sportom, razvoj sporta u školama i uključenje dece u sportske aktivnosti, izgradnja sportskih objekata), razvoj i unapređenje vrhunskog sporta (u odeljku o prioritetima navedeno na trećem mestu), uz postizanje vrhunskih rezultata na najvećim međunarodnim sportskim takmičenjima (očekuje se da će zahvaljujući merama koje će biti preduzete broj vrhunskih rezultata do 2018. godine biti povećan za $10-20 \%$ ).

Povodom koncepta vrhunskog sporta postavlja se nekoliko pitanja o kojima će biti reči u članku, a to su pitanje: osnova na kojima se zasniva vrhunski sport; uslova koje treba ispuniti kako bi se stekao status vrhunskog sportiste; efekata koji nastaju dobijanjem statusa vrhunskog sportiste; osnova za gubitak prava koja proističu iz statusa vrhunskog sportiste.

\section{OSNOVI KONCEPTA VRHUNSKOG SPORTA}

Koncept vrhunskog sporta se zasniva na četiri težišne tačke, u čijem definisanju učestvuju sportski, paradržavni i državni organi. Za funkcionisanje ovog koncepta neophodno je da se odrede: 1) discipline kojima se dodeljuje status vrhunskog sporta; 2) referentna takmičenja za praćenje rezultata; 3) kriterijumi i merila za rangiranje vrhunskih sportista; 4) pretpostavke za sportski i vansportski razvoj. ${ }^{18}$

1. Discipline koje imaju status vrhunskog sporta. - Iako ZOSRS sadrži

od 80-tih godina, kada se počelo sa uobličavanjem koncepta vrhunskog sporta, broj vrhunskih sportista od 1800 u 42 discipline, rastao tako da ih je 1995. godine bilo 5486 u 128 disciplina, a 2014. godine 6951. O tome: Simon, G., nav. delo, str. 367; La charte du sport de haut niveau, http://www.ffvb.org/data/files/dtn/ haut\%20niveau/charte_du_sport_de_haut_niveau.pdf; Les chiffres-clés du sport, http://www.sports.gouv. fr/IMG/pdf/chiffres-cles_du_sport_2015.p̄pdf, str. 10.

${ }_{14}$ Simon, G., nav. delo, str. 363; Concept du sport d'élite suisse, http://www.swissolympic.ch/fr/ Portaldata/41/

Resources/03_sport/verbaende/spitzensport_konzept/Spitzensport-Konzept_Schweiz_2010_05_01_ FR.pdf, str. 7

15 Simon, G., nav. delo, str. 362.

16 Simon, G. i dr., Droit du sport, Paris, 2012, str. 196.

17 Sl. glasnik RS, br. 1/15.

${ }^{18}$ Le sport de haut niveau c'est quoi ? http://www.sports.gouv.fr/pratiques-sportives/sportperformance/Sport-de-haut-niveau/article/Le-sport-de-haut-niveau-c-est-quoi. 
odrednicu o vrhunskom sportu, u zakonskim i podzakonskim pravilima se ne određuje eksplicitno koje sportske discipline (grane) imaju status vrhunskog sporta. Posredno bi se mogao izvući zaključak da tu spadaju grane povodom kojih, u cilju ostvarenja opšteg interesa, može da se realizuje državna finansijska podrška. Radi se o granama koje su od posebnog značaja za državu (čl. 118. st. 3. ZOSRS), čiji je spisak utvrđen u Pravilniku o sportskim granama od posebnog značaja za Republiku Srbiju. ${ }^{19} \mathrm{Za}$ razliku od srpskog prava, u Francuskoj je ovo pitanje rešeno tako što se status vrhunskog sporta priznaje po automatizmu olimpijskim disciplinama, kao i paraolimpijskim disciplinama, ukoliko se kao učesnik na takmičenju pojavljuje francuska ekipa. Druge discipline mogu da steknu taj status na osnovu sprovedenog postupka za priznanje i podnetog zahteva (u njemu treba da bude navedeno, između ostalog, da se radi o disciplini povodom koje se organizuje svetsko takmičenje svake dve godine, da na njemu učestvuje najmanje 25 ekipa sa četiri kontinenta, da su ekipe na jednom od prethodna dva takmičenja zauzele jedno od prvih osam mesta) ${ }^{20}$ shodno kriterijumima i odluci koju donosi Nacionalna komisija za vrhunski sport za period od četiri godine.

2. Referentna takmičenja za praćenje rezultata. - Kao referentna takmičenja uzimaju se Olimpijske igre, svetska prvenstva i prvenstva Evrope, druga prvenstva (na primer, Balkansko prvenstvo) i takmičenja povodom kojih sportisti na kraju godine zauzimaju određena mesta na rang-listama (primer, golfa ili tenisa).3. Kriterijumi i merila za rangiranje vrhunskih sportista. - Povodom rangiranja i utvrđivanja liste vrhunskih sportista primetna su različita rešenja u pogledu kategorija i organa koji vrše rangiranje, značaja kategorisanja za prava koja zahvaljujući tome stiču sportisti. Republika Srbija spada u grupu zemalja u kojoj kategorisanje ima značaja, pre svega, za ostvarivanje prava sportista na nacionalna priznanja, nagrade i stipendije. Dodeljivanje statusa vrhunskog sportiste regulisano je Pravilnikom o nacionalnoj kategorizaciji vrhunskih sportista. ${ }^{21}$ Njime se uređuju kriterijumi i merila za rangiranje sportista na osnovu rezultata, uzrasta, pola i nacionalne kategorizacije sportova. ${ }^{22}$ Shodno tome lice koje je državljanin Republike Srbije može da stekne status vrhunski sportista - zaslužni sportista, vrhunski sportista - međunarodni rang, vrhunski sportista - nacionalni rang (u ekipnim sportovima odgovarajući sportski status se dobija ako sportista ima najmanje 30\% nastupa u ekipi na sportskom takmičenju na osnovu koga se rezultati računaju). Sportski savez Srbije vrši rangiranje sportista za neolimpijske sportove, a Olimpijski komitet Srbije za olimpijske i paraolimpijske sportove.

19 U tom Pravilniku (S1. glasnik RS, br. 95/16) sportske grane su razvrstane u pet grupa (olimpijski sport - 43 grane; paraolimpijski - 26; ne paraolimpijski - 4; neolimpijski sport - 34; neolimpijski - ostali $-10)$.

20 Conditions a remplir pour obtenir la reconnaissance du caractere de haut niveau d'une discipline, http://www.sports.gouv.fr/IMG/archives/pdf/criteres_de reconnaissance_HN.pdf.

21 Sl. glasnik RS, br. 123/12.

22 Nacionalna kategorizacija sportova izvršena je Pravilnikom o nacionalnoj kategorizaciji sportova (Sl. glasnik RS, br. 25/13, 126/14) i to tako što su sve sportske grane razvrstane u šest kategorija. 
Rangiranje se vrši jedanput godišnje, o čemu se vodi nacionalna evidencija. ${ }^{23} \mathrm{U}$ Republici Hrvatskoj, na osnovu zahteva koji podnosi sportista, razvrstavanje se vrši na osnovu rešenja koje donosi Hrvatski olimpijski (paraolimpijski) odbor, odnosno savez gluvih, pri čemu se sportisti razvrstavaju na vrhunske (I., II., III. kategorija), vrsne (IV. kategorija) i darovite (V. i VI. kategorija) (čl. 6. ZOSRH). U Republici Crnoj Gori, unutar kategorije vrhunski sportista ne prave se razlike, a određuje se da se na osnovu ostvarenog rezultata može podneti zahtev za sticanje statusa vrhunskog sportiste od strane sportiste (sportske organizacije ili nacionalnog sportskog saveza) nadležnom organu uprave, o čemu donosi rešenje Direktor Uprave (čl. 3 - 5. Pravilnika o bližim uslovima i načinu sticanja statusa vrhunski sportista). ${ }^{24}$

U Francuskoj, kategorisanjem sportisti stiču korpus prava koja treba da doprinesu osiguranju i razvoju njihovih sportskih i ljudskih prava. Od 1982. godine status vrhunskog sportiste dobija se upisom na listu vrhunskih sportista, a na osnovu odluke koju donosi Ministar sporta (donosi je na osnovu predloga koji čini sportska federacija i pribavljenog mišljenja od strane Nacionalne komisije za vrhunski sport). ${ }^{25}$ Vrhunski sportisti se razvrstavaju u četiri kategorije: elita, seniori, prozvani, povratnici (čl. R 221 - 3. Zakona o sportu). Upis se vrši na period od godinu dana, osim kategorije „elita“ povodom koje upis važi dve godine, uz mogućnost obnavljanja pod istim uslovima. U „elitu“ mogu da budu svrstani sportisti koji učestvuju na Olimpijskim igrama, svetskim šampionatima, šampionatima Evrope ili na takmičenjima čiju listu utvrđuje Nacionalna komisija za vrhunski sport (ona definiše: pravce nacionalne politike u sferi vrhunskog sporta; discipline koje imaju status vrhunskog sporta; kriterijume, po disciplinama, za sticanje statusa vrhunskog sportiste; daje mišljenje o broju sportista koji treba da se nađu na listi vrhunskih sportista; zauzima stav o valjanosti programa za vrhunski sport) ${ }_{,}^{26}$ ako imaju zavidan plasman pojedinačno ili kao ekipa, shodno uslovima koje utvrđuje Nacionalna komisija. U kategoriju „seniora“ mogu da budu svrstani sportisti koji su izabrani od strane sportske federacije da učestvuju na zvaničnom međunarodnom takmičenju koje je referentno i za sticanje statusa „elita“, s tim što ne ispunjavaju uslove da se nađu na toj listi. U kategoriju „prozvanih“ upisuju se sportisti koji su izabrani da učestvuju na međunarodnom takmičenju koje je uvršćeno u listu takmičenja određene federacije. U kategoriju

${ }^{23}$ U matičnu evidenciju kategorisanih sportista upisuju se: ime, prezime, pol sportiste; datum i mesto rođenja; jedinstveni matični broj građana; adresa; rang (kategorija) i od kada; status (član sportske organizacije, samostalni profesionalni sportista); najvažniji postignuti sportski rezultati, odnosno rekordi; sportska grana i sportska disciplina; matična sportska organizacija; sportski savez; završena odgovarajuća škola; radni odnos (zaposlenje); registarski broj takmičarske knjižice i ko je izdao; rang takmičenja; nacionalno sportsko priznanje i druga priznanja; kazne zbog povrede anti-doping pravila; broj rešenja o upisu, odnosno brisanju iz matične evidencije (čl. 3. Pravilnika o sadržaju i načinu vođenja matičnih evidencija u oblasti sporta, Sl. glasnik RS, br. 74/11).

24 Sl. list CG, br. 31/15.

25 Ministar ne može da modifikuje predloženu listu sportista. Može da prihvati ili da je odbaci u celosti. O tome: Buy, F., nav. delo, str. 414.

26 Structures du sport de haut niveau - parcours de l'excellence Sportive 2014 - 2017, http://portailshn.creps-pdl.fr/wp-content/uploads/2016/01/Plaquette-HN-PdL-13janvier2016-light.pdf, str. 6 . 
„povratnika“ svrstavaju se sportisti koji su bili na listi „elita“ ili nekoj drugoj u trajanju od četiri godine, od čega su barem tri godine bili upisani na listi „,senior“. Niko od sportista ne može da bude upisan na listu ako nije predložen od federacije, ako nije učesnik međunarodnog takmičenja u sportskoj disciplini koja ima status vrhunskog sporta, ako ne zadovoljava kriterijume za sticanje statusa vrhunskog sportiste, ako ne navršava barem dvanaest godina u godini upisa, ako nije zaključio sporazum sa sportskom federacijom (čl. R $221-2$. Zakona o sportu). Sporazumom se definišu prava i obaveze sportiste i federacije u pogledu razvoja i socioprofesionalne podrške (praćenje treninga, nadzor i socioprofesionalno praćenje, uslovi i način pomoći od strane države), medicinske brige (osiguranje sportista, modaliteti medicinskog praćenja), takmičarske prakse (modaliteti izbora u nacionalnu ekipu, obaveze sportiste u pogledu ponašanja i oblačenja), poštovanja sportskih etičkih pravila (uslovi, prava i obaveze u pogledu korišćenja ličnog imidža sportiste, obaveze u pogledu predstavljanja javnosti slike o federaciji i sportskim vrednostima, poštovanje pravila o zabrani dopinga) (čl. D $221-2-1$. Zakon o sportu).

4. Pretpostavke za sportski i vansportski razvoj. - Mesto na podijumu nekog međunarodnog sportskog takmičenja rezultat je dugih i ozbiljnih priprema. Za ostvarenje takvog cilja neophodno je da budu zadovoljene određene pretpostavke, da se trasira put koji može dovesti do ostvarenja tog cilja. To podrazumeva da se moraju preduzeti odgovarajuće mere na sportskom planu, ali i sve druge koje će pospešiti razvoj jedne osobe kao ličnosti. Ukupan rast i sigurnost jednog sportiste je uslov bez koga, po pravilu, nema ni vrhunskih rezultata (sportski uspeh je neodvojiv od socioprofesionalnog uspeha). Zato je neophodno da se adekvatne mere preduzmu u tri ključna sektora, a to su sport, škola i individualno praćenje (podrška) u sferi zdravstva i rada. ${ }^{27}$ Shodno tome, u Francuskoj se u skladu sa projektom koji razrađuje svaka sportska federacija, a odobrava ministar, po pribavljenom mišljenju nadležne komisije za vrhunski sport, preduzima niz mera kojima se nastoji da se sportistima omogući da dostignu najviši sportski nivo, pruži neposredna finansijska podrška, omogući profesionalni razvoj, obezbedi potrebna zdravstvena i životna zaštita (projekat mogu da podnesu samo federacije u čijem su sastavu sportske discipline koje imaju status vrhunskog sporta). ${ }^{28}$ Aktivno učešće u razvoju sportista imaju specijalizovane institucije, kao što su institut za sport, sportske škole (u Francuskoj postoje škola za jahanje, za skijanje i alpinizam, za jedrenje), nacionalni sportski centri. ${ }^{29}$

U Republici Srbiji, za razliku od Francuske, ne postoji razrađen sistem mera kojima bi se omogućio sveobuhvatni razvoj i sigurnost vrhunskih sportista, kako u sferi sporta, tako i van sporta. U osnovi, i u Republici Srbiji se pitanje vrhunskog sporta rešava putem predlaganja i usvajanja programa (predlagači mogu da budu Olimpijski komitet, Paraolimpijski komitet i Sportski savez Srbije), kojima se

27 Sport de haut niveau, http://www.sports.gouv.fr/pratiques-sportives/sport-performance/Sport-dehaut-niveau/

28 Buy, F. i dr., nav. delo, str. 408.

29 Isto, str. 409. 
isključivo reguliše finansiranje predloženih sportskih aktivnosti. ${ }^{30}$ Činjenica da se vrhunski sportisti (rezultati) spominju u Pravilniku o odobravanju i finansiranju programa ..... samo na dva mesta (čl. 4. i 26) slikovito ukazuje da vrhunskom sportu (sportistima) nije posvećena neka posebna pažnja, da je to samo jedno od pitanja koje se razmatra u istoj ravni sa svim drugim pitanjima iz sfere opštih interesa u oblasti sporta.

\section{EFEKTI OD STATUSA VRHUNSKOG SPORTISTE}

Vrhunski sportisti temelje svoj status na odnosu koji okruženje (država, sportska federacija, teritorijalna zajednica, privatni sektor) uspostavlja sa njima. Iz tog odnosa za sportiste nastaju obaveze prema sportskoj federaciji i državi, ali i brojna prava (postaju korisnici: mera i pomoći koja je u funkciji njihovog sportskog razvoja; nadoknade troškova koji nastaju bavljenjem sportom; socioprofesionalnog razvoja - integracije u društvo, zapošljavanje). ${ }^{31}$ Za sportiste su od posebnog značaja personalizovane (individualizovane) mere, koje mogu da koriste, za razliku od drugih sportista, zahvaljujući statusu koji imaju. Tu spadaju: 1) mere finansijske pomoći; 2) mere podrške obrazovanju; 3) mere zapošljavanja; 4) mere medicinske zaštite.

1. Mere finansijske pomoći. - Finansijska podrška koja se dodeljuje sportistima od strane države može da ima različite oblike (stipendiranje; povremena pomoć usmerena ka pokrivanju troškova koji se ad hoc pojavljuju povodom preduzetih sportskih aktivnosti; pokrivanje poslodavcima dela zarade sportista za vreme njihovog odsustva sa posla; pokrivanje troškova sportskih priprema po podnetom računu; nagrade za ostvaren plasman - u Francuskoj nagrada za osvojenu zlatnu medalju na Olimpijskim i Paraolimpijskim igrama iznosi $50.000 €$, srebrna 20.000 $€$, bronzana $13.000 €)^{32}$

U Republici Srbiji, sportistima, državljanima Republike Srbije, koji kao reprezentativci Republike Srbije osvoje medalju na referentnim takmičenjima, dodeljuje se: nacionalno sportsko priznanje u vidu doživotnog mesečnog novčanog primanja nakon navršenih 40 godina života i novčana nagrada ${ }^{33}$ (čl. 123. st. 1. i 2.

30 Ministar bliže uređuje: kriterijume i način odobravanja programa, odnosno projekta i dodele sredstava; izgled i sadržinu predloga programa, odnosno projekta i dokumentaciju koja se uz predlog podnosi; sadržinu i izgled izveštaja o realizaciji programa, način i postupak kontrole realizacije odobrenih programa, odnosno projekta - čl. 118. st. 11. Zakona o sportu i čl. 1. st. 1. Pravilnika o odobravanju i finaniranju programa kojima se ostvaruje opšti interes u oblasti sporta (Sl. glasnik RS, br. 64/16).

${ }^{31}$ La charte du sport de haut niveau, http://www.ffvb.org/data/files/dtn/haut\%20niveau/charte_du_ sport_de_haut_niveau.pdf.

32 Dispositifs d'aides aux sportif(ve)s de haut niveau, http://www.sports.gouv.fr/pratiques-sportives/ sport-performance/Sport-de-haut-niveau/article/Les-dispositifs-d-aides-aux-sportif-ve-s-de-haut-niveau.

33 ZOSRH i ZOSRCG regulišu pitanje dodele nacionalnih priznanja i novčanih nagrada, $\mathrm{s}$ tim što su primetne razlike u pogledu starosti kada se može steći pravo na nacionalno priznanje (u RH to pravo se stiče sa navršenih 45 godina života) ili iznosa koji pripada sportistima (u RH, iznos nagrada je određen $u$ kunama i to za pojedinačne sportove: zlato 104.000 kuna, srebro 65.000, bronza 46.000 kuna - regulisano Uredbom o kriterijumima za dodeljivanje državnih nagrada za vrhunska sportska postignuća). 
ZOSRS). ${ }^{34}$ Osim toga, vrhunskim sportistima amaterima za sportsko usavršavanje može da se dodeli stipendija, a vrhunskim sportistima sa posebnim zaslugama za razvoj sporta u Republici Srbiji može da se dodeli novčana pomoć (čl. 126. st. 1. ZOSRS). ${ }^{35}$

2. Mere podrške obrazovanju. - Đaci i studenti imaju pravo na specijalni režim obrazovanja kako bi mogli nesmetano da se bave sportskim aktivnostima (čl. 2219 i 221-10. Zakona o sportu Francuske). Kada se radi o fakultetima, predviđeno je da studenti imaju pravo da studiraju u skladu sa programima prilagođenim njihovim potrebama, da se obrazuju na daljinu i koriste audio-vizuelna sredstava telekomunikacije (čl. 611-4. Zakona o obrazovanju Francuske); da im bude pružena podrška na planu režima studija (uslovi za odsustvo sa predavanja i praktične nastave, pomeranje datuma polaganja ispita), na sportskom (korišćenje univerzitetskih sportskih objekata van uobičajenih termina, prisustvo trenera, besplatna studentska karta), na socijalnom planu (redukcija cene studiranja, prioritet u pogledu smeštaja, mogućnost smeštaja tokom letnjih meseci, smanjenje zakupnine). ${ }^{36}$

U Republici Srbiji, osim preporuke koja se nalazi u Strategiji razvoja sporta (odeljak 7.1) o tome da vrhunskim sportistima treba obezbediti posebne uslove pri upisu na studije na visokoškolskim ustanovama i posebne uslovi studiranja, nema zakonskih odredbi koje bi regulisale ovo pitanje. Za razliku od toga, u Republici Hrvatskoj sportisti imaju pravo na subvencionisanu školarinu i posebne uslove pod kojima mogu da pohađaju i završe osnovno i srednješkolsko obrazovanje (čl. 7. st. 4. i 5. Zakona o sportu). Ako se ima u vidu da su obaveze studenata najveće, iznenađuje odredba prema kojoj oni mogu da imaju pravo na posebne uslove studiranja samo ako to nije protivno načelima autonomije sveučilišta.

3. Mere zapošljavanja. - Obaveze vrhunskih sportista, koje imaju povodom treninga i takmičenja, teško da mogu da se dovedu u sklad sa profesionalnim aktivnostima na poslu i mogućnostima da se nađe poslodavac koji će prihvatiti nekoga da radi, a da ne može da bude u potpunosti posvećen poslu. Radi prevazilaženja navedenih prepreka u Francuskoj se preduzimaju različite mere koje treba da olakšaju zasnivanje i vršenje aktivnosti iz radnog odnosa. Te mere se realizuju u okviru javnog sektora, zbog čega ministar sporta zaključuje sporazume sa pet ministarstava (obrazovanje, unutrašnji poslovi, odbrana, finansije, pravda)

34 Bliži uslovi, način isplate i visina nacionalnih sportskih priznanja i novčanih nagrada (u pojedinačnim sportovima za osvojeno zlato na OI ili POI isplaćuje se 45.000 evra, za srebro 40.000 evra, za bronzu 35.000 evra - čl. 6) za poseban doprinos razvoju i afirmaciji sporta utvrđeni su u Uredbi o nacionalnim sportskim priznanjima i novčanim nagradama (Sl. glasnik RS, br. 22/16).

35 Bliži uslovi i kriterijumi za stipendiranje vrhunskih sportista amatera za sportsko usavršavanje i za dodelu novčane pomoći vrhunskim sportistima sa posebnim zaslugama, kao i kriterijumi za utvrđivanje visine mesečnog iznosa stipendije i visine novčane pomoći regulisani su Pravilnikom o bližim uslovima $\mathrm{i}$ kriterijumima za stipendiranje vrhunskih sportista amatera za sportsko usavršavanje i za dodelu novčane pomoći vrhunskim sportistima sa posebnim zaslugama (Sl. glasnik RS, br. 124/12).

36 Université libre de Bruxelles Statut du sportif de haut niveau, http://www.iclub.be/ doc/107/ Statut \%20 Sportif\%20de\%20haut\%20niveau\%202016\%202017.pdf. 
sa kojima se reguliše pitanje zapošljavanja i status sportista. ${ }^{37}$ Pravni okvir za preduzimanje tih mera je određen u Zakonu o sportu gde se precizira da: sportista koji radi u javnom sektoru ima pravo na pogodnosti koje treba da mu omoguće da trenira i učestvuje na takmičenjima bez štete po profesionalnu karijeru (čl. 2217); sportisti mogu da učestvuju na konkursima koje raspisuje javni sektor iako ne ispunjavaju potrebne uslove (čl. 221-3); starosni limit za zasnivanje radnog odnosa ne primenjuje se na vrhunske sportiste (starosni limit se ne primenjuje na njih ni kada izgube status vrhunskog sportiste u trajanju koje odgovara dužini trajanja njihovog statusa vrhunskog sportiste, $\mathrm{s}$ tim što taj period ne može da bude duži od pet godina) (čl. 221-7).

4) Mere medicinske zaštite. - Vrhunski sportisti imaju pravo, ali i obavezu da se podvrgnu periodičnim zdravstvenim pregledima određene vrste (u jednom delu vrsta pregleda zavisi i od prirode sportske discipline sa kojom se bave), shodno pravilima koja definišu nadležna ministarstva, odnosno pojedine sportske federacije.

Prema Pravilniku o utvrđivanju zdravstvene sposobnosti sportista za obavljanje sportskih aktivnosti i učestvovanje na sportskim takmičenjima ${ }^{38}$ opšta i posebna zdravstvena sposobnost sportista utvrđuje se u periodu od šest meseci (četiri meseca za sportiste za koje je ta obaveza utvrđena aktima granskih saveza) pre održavanja sportskog takmičenja (čl. 3), a vrši se putem prethodnog (vrši se pre početka bavljenja sportom), periodičnog (vrši se radi provere zdravlja tokom bavljenja sportom) i vanrednog (vrši se kada posebne okolnosti to opravdavaju - bolest, povrede, istek kazne zbog povrede anti-doping pravila, prekid bavljenja sportom $u$ periodu dužem od godinu dana) zdravstvenog pregleda (čl. 6). Na osnovu izvršenih pregleda daje se ocena zdravstvenog stanja (sposoban, sposoban sa ograničenjem, privremeno nesposoban, nesposoban za predloženu sportsku granu, nesposoban, ocena i mišljenje se ne mogu dati zbog) za učešće na sportskim takmičenjima (čl. 19. i 20).

\section{GUBITAK PRAVA I STATUSA VRHUNSKOG SPORTISTE}

U Republici Srbiji, ali i u zemljama u okruženju, mali je broj odredbi kojima se reguliše gubitak prava koja proističu iz statusa vrhunskog sportiste. Takva odredba se susreće u Uredbi o nacionalnim sportskim priznanjima i novčanim nagradama, gde se u čl. 14. određuje da ukoliko nosilac nacionalnog sportskog priznanja svojim ponašanjem ili učešćem u aktivnostima koje nisu u skladu sa zakonom, sportskim pravilima ili drugim opštim aktima organizacija u oblasti sporta šteti ugledu sporta, i na taj način, ugledu Republike Srbije, Vlada može, na predlog Ministarstva, rešenjem odlučiti da ne dodeli, odnosno ukine nacionalno sportsko priznanje

37 O tome: Buy, F. i dr., nav. delo, str. 415; Dispositifs d'aides aux sportif(ve)s de haut niveau, http:// www.sports.gouv.fr/pratiques-sportives/sport-performance/Sport-de-haut-niveau/article/Les-dispositifsd-aides-aux-sportif-ve-s-de-haut-niveau.

38 Sl. glasnik RS, br. 15/12. 
(protiv rešenja može se voditi upravni spor). Slično tome, u Republici Crnoj Gori se određuje da vrhunskom sportisti, koji neopravdano ne ispunjava obaveze da na poziv nacionalnog sportskog saveza učestvuje i nastupa za reprezentaciju Crne Gore i postupa u skladu sa međunarodnim pravilima i pravilima nacionalnog sportskog saveza, može prestati pravo na doživotnu mesečnu naknadu (čl. 29. ZOSRCG). Ili, u Republici Hrvatskoj, trajna mesečna novčana naknada gubi se ako sportista više ne ispunjava propisane uslove (hrvatsko državljanstvo, prebivalište u RH, nije pravnosnažno osuđen na bezuslovnu kaznu zatvora za počinjeno krivično delo) (čl. 81.a ZOSRH).

Za razliku od napred navedenog, u Francuskoj se pravi razlika između nekoliko situacija koje mogu da budu od uticaja na status i prava vrhunskog sportiste. U osnovi, vrhunski sportista gubi status, kao i prava koja ima po tom osnovu, ako prestane da ispunjava propisane kriterijume. ${ }^{39}$ Osim toga, u Zakonu o sportu definisani su i neki posebni razlozi koji mogu da dovedu do gubitka ili suspenzije statusa vrhunskog sportiste, a time i prava koja po tom osnovu ima (čl. R221-14). Odluku o tome donosi ministar sporta, a razlikuje se nekoliko situacija kad do toga može da dođe. Prvo, kada se odluka donosi na predlog nadležne sportske federacije. To je slučaj kada je sportisti izrečena disciplinska mera zbog povrede pravila federacije. U ovom slučaju ministar nema pravo da samostalno, bez predloga federacije, izrekne bilo kakvu meru, niti preduzete disciplinske mere povlače automatski suspenziju ili gubitak prava vrhunskog sportiste. ${ }^{40}$ Drugo, kada se odluka donosi na predlog federacije ili po sopstvenoj inicijativi ministra. Do toga može doći: u slučaju povrede antidoping pravila (u ovom slučaju i Anti-doping komisija može da zahteva od ministra izricanje sankcije, s tim što se u tom slučaju prava sportiste suspenduju dok odluka o povredi anti-doping pravila ne postane konačna); ako ne izvršava preuzete obaveze; ako je izvršio određene radnje zbog kojih može da bude osuđen ${ }^{41}$ (nasilje, seksualni delikti, trgovina narkoticima, upotreba ili navođenje na upotrebu narkotika). Treće, kada se odluka donosi neposredno od strane ministra. To je moguće u slučaju kada sportista zbog zdravstvenog stanja više ne može da upražnjava sportske aktivnosti na potrebnom nivou ili ako se ne podvrgava obaveznim periodičnim medicinskim pregledima (čl. R221-15). Pre nego što se izrekne mera suspenzije ili gubitka statusa, vrhunski sportista se poziva da se o svemu usmeno ili pismeno izjasni (čl. R221-16).

\section{ZAKLJUČAK}

Nesporno je da je razvoj sporta, i s tim u vezi ulaganja koja se vrše, u javnom, opštedruštvenom interesu. Brojni interesi čine opravdanim ulaganje u sport. Među njima, zbog svoje kompleksnosti, izdvaja se interes za ulaganje u vrhunski sport,

39 Buy, F. i dr., nav. delo, str. 416.

40 Isto, str. 416.

41 S obzirom da je ministru dato pravo na izricanje mera u fazi kada povodom učinjenog dela još ne postoji pravnosnažna presuda, čime se vređa prezumpcija nevinosti, prisutan je stav da prava sportiste do donošenja presude mogu da budu samo suspendovana. O tome: Buy, F. i dr., nav. delo, str. 417. 
odnosno vrhunske sportiste. S obzirom na vreme nastanka (radi se o interesu koji se razvija i prepoznaje u različitim državama u poslednjih tridesetak godina), moglo bi se reći da se radi o „mladom“ interesu, ali interesu koji zaokuplja najveći deo pažnje, u svakom pogledu, svake države. Na prvi pogled to je čudno. Jer, ako svako društvo treba da stremi da bude zdravo, te da u funkciji ostvarenja tog cilja treba da ulaže u sport, svako društvo ne mora da razvija niti ulaže u vrhunski sport. Međutim, u praksi se dešava nešto što je suprotno očekivanom - ulaganja u vrhunski sport su sve veća, povećava se broj disciplina kojima se daje status vrhunskog sporta, kao i broj vrhunskih sportista. Razlog tome treba tražiti u opšteprihvaćenom stavu da je vrhunski sport najbolje sredstvo za promociju određene države, njene politike i vrednosti.

U cilju podsticaja vrhunskih rezultata često se koriste različiti vidovi novčanih davanja. Za sportiste takva vrsta podrške je bez sumnje značajna. Međutim, kako život nije samo sport, za sportiste bi bilo značajno da kako za vreme sportske karijere, tako i nakon njenog završetka, budu korisnici podrške koja ce im olakšati bavljenje vrhunskim sportom, kao i drugim aktivnostima. Pri tome, sportisti moraju imati jasnu predstavu o posledicama koje će nastati ako ne postižu određene rezultate ili se ne pridržavaju određenih pravila. Dakle, pitanja koja se otvaraju povodom vrhunskog sporta su brojna. De lege ferenda trebalo bi ih regulisati posebnim pravilima i predvideti njihovu individualizaciju kroz sporazume koji bi se zaključivali između sportske federacije i vrhunskog sportiste.

\section{HIGH-LEVEL SPORT}

The concept of high-level sport, which is based on providing support to achieve top results, began to develop in the second half of the last century. In some countries, high-level sport is based on the financial support that the state provides to top-class athletes, while others combine financial support with other measures to facilitate athletes engaged in sports or other related activities. In this regard, article deals with the issues concerning: the basic principles of high-level sport; conditions for acquiring the status of top-class athlete; effects resulting from the status of top-class athlete; the basis for the loss of rights of top-class athlete.

Key words: high-level sport, top-class athlete, status, competition, measures 